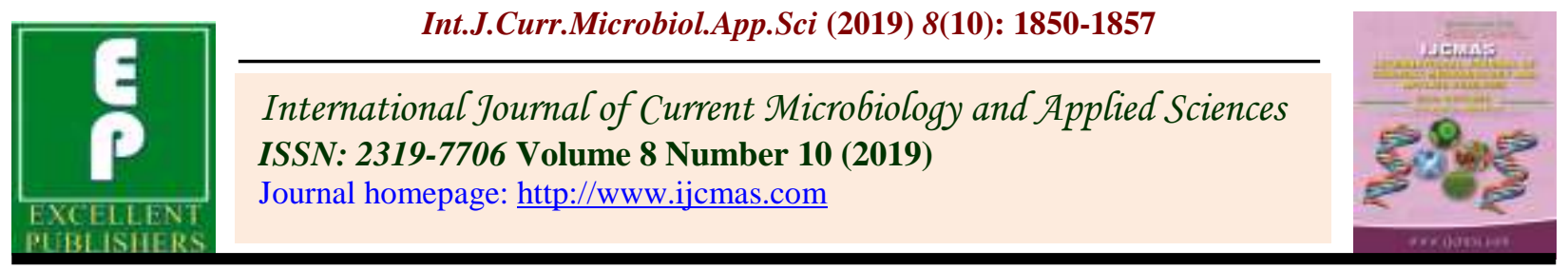

Original Research Article

https://doi.org/10.20546/ijcmas.2019.810.215

\title{
Effect of Different Level of Natural Antioxidant Aloe vera in Instant Functional Chicken Noodles
}

\author{
M. Pavan*, T. Sathu, B. Sunil, V. N. Vasudevan, A. Irshad and Silpa Sasi \\ Department of Livestock Products Technology and Meat Technology Unit, College of \\ Veterinary and Animal Sciences, Mannuthy, Kerala-680 651, India \\ *Corresponding author
}

\section{Keywords}

Aloe vera, Chicken,

Noodles, Texture,

Sensory and colour

Article Info

Accepted:

15 September 2019

Available Online:

10 October 2019

\section{A B S T R A C T}

Noodles with unique taste are coveted by consumers. Noodles became popular quickly all over the world due to its easy preparation, fast urbanization, changing food habits and busy life style. The current study was conducted to evaluate the effect of natural antioxidant Aloe vera (AV) at 3 different levels viz., 0.3, 0.6 and 0.9 percent added over and above the control chicken noodle formulation. The dough $\mathrm{pH}$ and product $\mathrm{pH}$ did not show any significant difference between $T_{1}, T_{2}$ and $T_{3}$ and the values were in the range of $7.153-$ 7.190 and $7.142-7.218$ respectively. The Water Absorption Index, Water Solubility Index and Swelling Power Index of $T_{1}, T_{2}$ and $T_{3}$ did not show any significant difference between them and the values were in the range of 4.872 $-5.353,3.767-4.030$ and $4.874-5.152$ respectively. The lightness, redness and yellowness did not show any significant difference between the test samples and the values were in the range of $43.755-44.212,13.298-13.555$ and $30.475-30.637$. The sensory evaluation revealed no significant difference for appearance and colour, flavor, softness and stickiness. AV at 0.6 per cent and above imparted bitter taste in the chicken noodles.

\section{Introduction}

Noodles are popular as a major staple food in most of the countries of the world. Noodles are popular across the world due to its easy preparation, fast urbanization, changing food habits and busy life style. Chicken is the second most consumed meat in the world, behind pork. Chicken meat is one of the most recommended meat by experts, to incorporate high quality proteins and nutrients into our diet. In addition, it has a low-fat content which makes it ideal for any type of diet. Several research works had been reported on the use of composite flour in noodle production but, there are less works on incorporation of natural antioxidant in noodles. Synthetic antioxidants have fallen under scrutiny due to 
potential toxicological effects (Naveena et al., 2008).

Aloe barbadensis (Aloe Vera) belongs to the genus of the Liliaceous plants and has 75 active components in it, which meet the natural cosmetic and pharmaceutical industry requirements (Vogler and Ernst, 1999). Aloe verais known for its medicinal uses, recently it has attracted the attention of the food industry.

Because of its medicinal properties, it has been used in many functional foods like drinks, beverages and ice- cream and also to preserve grapefruit quality as an edible coating (Valverde et al., 2005). Aloe vera is used as a contemporary folk remedy traditionally and has many medicinal properties and can be used in the prevention of arthritis, diabetes, cancer, constipation, heartburns, stomach aids, increase absorption of nutrients and also in neutralizing toxic elements. This plant can also be used against various common pathogenic bacteria (Saritha et al., 2010). Jiang and Xiong (2016) has reported that many exogenous phenolic compounds which act as an antioxidant are derived from dietary fruits, legumes, vegetables, spices and herbs are used in processed meats that contributes antioxidant pool and when the body is exposed to a high degree of radical stress the antioxidants play a major role in neutralizing them and are more essential.

Due to the reported health benefits, the consumption of aloe vera has fetched tremendous attention of food industries in recent years. However it still remains underutilized in terms of production of value added food materials, especially in meat products. The use of aloe vera is a new approach for reaping the health benefit properties of the aloe vera in foods.

Keeping in view of all the above facts, the present study was envisaged the use ofaloe vera as an natural antioxidant in the development of functional meat products. The present study was designed to evaluate the effect of different levels of aloe vera powder on physicochemical properties, water hydration properties and sensory profile of noodles standardised with $70 \%$ chicken.

\section{Materials and Methods}

\section{Chicken}

Spent chicken of 1.5 to $1.75 \mathrm{~kg}$ live body weight procured from the local market were scientifically slaughtered and dressed under hygienic conditions at Meat Technology Unit, Mannuthy. The dressed carcasses were stored under freezer conditions at $\left(-23 \pm 1^{0} \mathrm{C}\right)$ until thawed at $4 \pm 1^{\circ} \mathrm{C}$ before used for preparation of noodles. The dressed spent chicken is pressure cooked and deboned. The deboned chicken meat is minced in mincer (MADO primus Model MEW 613, Germany) for three times using $6 \mathrm{~mm}$ plate and mixed with control formulation.

\section{Vegetable oil}

Refined sunflower oil (Sundrop) was used throughout the study for frying.

\section{Spice mixture}

A spice mix was prepared in the department specially for chicken noodles was used.

\section{Natural antioxidants}

Aloe vera-Suppied by Heilen Biopharm Face and Hair Care Natural Food Grade Aloe Vera Powder.

The formulation of control noodles was standardized by conducting several trials. The standardized control formulation was used for the entire studies (Table 1). 


\section{Preparation of control noodles}

The ingredients such as wheat flour, rice flour, maida flour, salt, sodium bicarbonate, potato starch, wheat gluten, guar gum and polyphosphates were used in the formulation of control noodles. Several trials were conducted to standardize the flour and chicken per cent in the control formulation. The sodium bicarbonate, potato starch, wheat gluten, guar gum and polyphosphates were mixed separately in hot water and then added to the flour mix. The flour mix prepared is put in to the "automatic pasta making machine" Dolly GB (Italy), and is kneaded for $10 \mathrm{~min}$ and water is added to it at $33 \%$ of control flour formulation and approximately $12 \%$ of chicken stock solution in chicken noodles to make dough of proper consistency and extruded. The prepared raw noodles were then deep fat fried in sunflower oil at $180^{\circ} \mathrm{C}$ in electric single tank fryer. (Toastmaster model no. E-DZ-4L)for 45 secondsand then driedin hot air oven at $100^{\circ} \mathrm{C}$ for $30 \mathrm{~min}$. The dried noodleswere cooled at room temperature and then packed aerobically in laminated pouches (PE/AL/PA) and stored in dry place at ambient temperature.

\section{Quality parameters analysed}

\section{pH}

The dough $\mathrm{pH}$ and the product $\mathrm{pH}$ of the noodles from all the treatments and control, was determined using a combined electrode digital $\mathrm{pH}$ meter $(\mu \mathrm{pH}$ system 362, Systronics, India) as per procedure of AOAC (2012).

\section{Water activity $\left(\mathrm{a}^{\mathrm{w}}\right)$}

For determination of $a_{w}$, the samples were cut into small pieces and filled in the sample cup up to the mark. The filled sample cup was kept in the measurement chamber of Lab swift $a_{w}$ meter (Novasina, Switzerland). The readings were taken, when the stable $a_{w}$ was on in the display (Cabonell et al., 2005).

\section{Cooking yield percentage}

The weights of fresh extruded noodles before and after frying stage of preparation were recorded. Product yield was expressed in percentage. The fried noodles are referred as raw noodles throughout this thesis. (Berry et al., 1992).

Cooking yield $(\%)$

$=\underline{\text { Weight of extruded fried noodles }} \times 100$

Weight of fresh extruded noodles

\section{Water hydration properties}

The water absorption index (WAI), water solubility index (WSI)and swelling power index (SPI) of the rice flour samples were determined according to a reported method (Ohishi et al., 2007) with slight modifications. $1 \mathrm{~g}$ raw noodle was dispersed in $20 \mathrm{~mL}$ deionized water and agitated at $25^{\circ} \mathrm{C}$ and $100^{\circ} \mathrm{C}$ for 30min, respectively. After centrifuging the dispersion at $15,000 \mathrm{~g}$ for 30 min, the supernatant was dried in a hot air oven at $105^{\circ} \mathrm{C}$ until a constant weight was obtained. WAI, WSI and SPI were calculated by the following formulae.

WAI =Wet sediment weight $/$ dry sample weight

WSI $=($ Dry supernatant weight $/$ dry sample weight $) \times 100$

SPI $=($ Wet sediment weight $\times 100 /$ Dry sample weight (100 - dry supernatant)

\section{Colour parameters}

Colour of the steam raw noodles sample was determined objectively as per Page et al., 
(2001) using Hunter Lab Mini Scan XE Plus Spectrophotometer (Hunter Lab, Virginia, USA) with diffuse illumination. The instrument was set to measure Hunter $\mathrm{L}^{*}, \mathrm{a}^{*}$ and $b^{*}$ using illuminant $45 / 0$ and $10^{\circ}$ standard observer with an aperture size of $2.54 \mathrm{~cm}$. It was calibrated using black and white calibration tiles before starting of the measurement and colorimeter score recorded with ' $L$ ' of black equals zero and ' $L$ ' of white equals 100 , 'a' of lower numbers equals more green (less red), higher numbers equals more red (less green) and ' $b$ ' of lower numbers equals more blue (less yellow), higher numbers equals yellow (less blue). The colour coordinates $\mathrm{L}^{*}$ (lightness), $\mathrm{a}^{*}$ (redness) and $\mathrm{b}^{*}$ (yellowness) of the samples were measured thrice and mean values were taken.

\section{Sensory evaluation}

The sensory evaluation was conducted by serving hot noodles cooked with the spicemix (4gm) that was developed in the department. $70 \mathrm{gm}$ of noodles was cooked in $420 \mathrm{ml}$ for 10 minutes at $120^{\circ} \mathrm{C}$ in an induction cooker.

The Sensory attributes of the noodles were assessed organoleptically using 8 point Hedonic scale score card with the help of seven semi-trained taste panelists drawn from the Department of Livestock Products Technology, Mannuthy, Thrissur, Kerala, India. The average of the individual scores was taken as the score for the particular attribute (Sirichokworrakit et al., 2015).

\section{Results and Discussion}

$\mathrm{T}_{1}, \mathrm{~T}_{2}$ and $\mathrm{T}_{3}$ samples were prepared by incorporating $\mathrm{AV}$ at level 0.3 per cent, 0.6 per cent and 0.9 per cent respectively in table 2 . The best level of natural antioxidantaloe vera was selected primarily based on the physicochemical properties, water hydration, colour values and sensory attributes.

\section{Physico-chemical properties}

The physico-chemical properties of the functional chicken noodles with addition of different levels of Aloe vera (AV) in $\mathrm{T}_{1}, \mathrm{~T}_{2}$, $\mathrm{T}_{3}$ are presented in Table 2 . The dough $\mathrm{pH}$ and product $\mathrm{pH}$ did not show any significant difference between $T_{1}, T_{2}$ and $T_{3}$ and the values were in the range of $7.153-7.190$ and $7.142-$ 7.218 respectively. The aloe vera incorporation progressively increased the dough $\mathrm{pH}$ and product $\mathrm{pH}$ with increase in aloe vera level.Simlarly,McCarthy et al., (2001) found $\mathrm{pH}$ of pork patties as $4.18 \pm 0.33$ on the $0^{\text {th }}$ day of preparation which was lower than control patties due to the addition of alovera andQin et al.,(2013) reported no remarkable variation in $\mathrm{pH}$ by incorporation of natural antioxidants in ground pork meat, but it was found to have relatively reduced $\mathrm{pH}$ from $5.88-5.61$ over a period of 12 days of storage. The water activity and product yield did not show any significant difference between $\mathrm{T}_{1}, \mathrm{~T}_{2}$ and $\mathrm{T}_{3}$ and the values were in the range of $0.507-0.513$ and 95.894 - 96.104 respectively. Though there was no significant difference, the water activity increased with increase in the AV level and it may be because of the gelation property of the AV whereas, the frying yield decreased with the increase in the level of aloe vera.

\section{Water hydration properties}

The Water Hydration Properties of the functional chicken noodles with addition of different levels of Aloe vera (AV) are presented in Table 2 .

The Water Absorption Index, Water Solubility Index and Swelling Power Index of $T_{1}, T_{2}$ and $\mathrm{T}_{3}$ did not show any significant difference between them and the values were in the range of $4.872-5.353,3.767-4.030$ and $4.874-$ 5.152 respectively. With increase in level of Aloe vera increased the WAI and SPI whereas WSI decreased. 
Table.1 Formulary for the preparation of control noodles

Ingredients
Control Noodles $(\%)$

$\begin{array}{ll}\text { I. 1. Chicken } & 41.18 \% \\ \text { 2. Maida flour } & 29.48 \% \\ \text { 3. Wheat flour } & 14.7 \% \\ \text { 4. Rice flour } & 14.7 \% \\ \text { II. 1. Salt } & 3 \% \\ \text { 2. Sodium bicarbonate } & 0.5 \% \\ \text { 3. Potato Starch } & 5 \% \\ \text { 4. Wheat gluten } & 0.4 \% \\ \text { 5. Guar gum } & 0.2 \% \\ \text { Polyphosphate } & 0.2 \%\end{array}$

*aloe vera and II were added over and above the standardised control formulation of I.

Table.2 Physico- chemical, Water hydration and Colour parameters of the instant chicken noodles

\begin{tabular}{|c|c|c|c|c|c|}
\hline Treatments & $\mathbf{T}_{\mathbf{1}}$ & $\mathbf{T}_{\mathbf{2}}$ & $\mathbf{T}_{\mathbf{3}}$ & $\begin{array}{c}\mathbf{F}- \\
\text { Value }\end{array}$ & $\begin{array}{c}\mathbf{p}- \\
\text { Value }\end{array}$ \\
\hline Dough pH & $7.153 \pm 0.013$ & $7.178 \pm 0.04$ & $7.190 \pm 0.068$ & $0.166^{\mathrm{ns}}$ & 0.848 \\
\hline Product pH & $7.142 \pm 0.017$ & $7.227 \pm 0.07$ & $7.218 \pm 0.053$ & $0.815^{\mathrm{ns}}$ & 0.461 \\
\hline Water & $0.507 \pm 0.002$ & $0.509 \pm 0.001$ & $0.513 \pm 0.002$ & $2.455^{\mathrm{ns}}$ & 0.120 \\
Activity & & & & & \\
\hline Product yeild & $96.104 \pm$ & $95.903 \pm$ & $95.894 \pm$ & $0.338^{\mathrm{ns}}$ & 0.719 \\
& 0.255 & 0.176 & 0.172 & & \\
\hline WAI & $4.872 \pm 0.204$ & $5.263 \pm 0.069$ & $5.353 \pm 0.135$ & $3.055^{\mathrm{ns}}$ & 0.077 \\
\hline WSI & $4.030 \pm 0.253$ & $3.843 \pm 0.041$ & $3.767 \pm 0.027$ & $0.831^{\mathrm{ns}}$ & 0.455 \\
\hline SPI & $4.874 \pm 0.204$ & $5.061 \pm 0.067$ & $5.152 \pm 0.130$ & $0.959^{\mathrm{ns}}$ & 0.406 \\
\hline L* & $43.755 \pm$ & $43.827 \pm$ & $44.212 \pm$ & $2.663^{\mathrm{ns}}$ & 0.102 \\
& 0.170 & 0.189 & 0.057 & & \\
\hline $\mathbf{a}^{*}$ & $13.555 \pm$ & $13.350 \pm$ & $13.298 \pm$ & $1.804^{\mathrm{ns}}$ & 0.199 \\
\hline $\mathbf{b}^{*}$ & 0.087 & 0.058 & 0.141 & & \\
\hline & $30.603 \pm$ & $30.637 \pm$ & $30.475 \pm$ & $0.730^{\mathrm{ns}}$ & 0.930 \\
\hline
\end{tabular}

ns- non significant, means with same superscript have no significant difference between them. The values are expressed as their Mean \pm Standard error. (Number of observations $=24$ )

T1 -0.3 per cent Aloe vera (AV) L*- Lightness T2 - 0.6 per cent Aloe vera (AV) a*- Redness

T3 - 0.9 per cent Aloe vera (AV) b*- Yellowness
WAI- Water Absorption Index WSI- Water Solubility Index SPI- Swelling Power Index 
Table.3 Effect of different level of Aloe vera on ${ }^{(\#)}$ Sensory attributes of instant chicken noodles

\begin{tabular}{|c|c|c|c|c|c|}
\hline Treatments & $\mathbf{T}_{\mathbf{1}}$ & $\mathbf{T}_{\mathbf{2}}$ & $\mathbf{T}_{\mathbf{3}}$ & $\begin{array}{c}\text { Chi-square } \\
\text { Value }\end{array}$ & p- Value \\
\hline $\begin{array}{c}\text { Appearance } \\
\text { and colour }\end{array}$ & $7.417 \pm 0.154$ & $7.167 \pm 0.105$ & $7.250 \pm 0.017$ & $1.737^{\mathrm{ns}}$ & 0.420 \\
\hline Flavour & $6.833 \pm 0.279$ & $6.708 \pm 0.262$ & $6.875 \pm 0.011$ & $0.226^{\text {ns }}$ & 0.893 \\
\hline Taste & $6.792 \pm 0.262$ & $6.458 \pm 0.319$ & $6.667 \pm 0.014$ & $0.788^{\text {ns }}$ & 0.674 \\
\hline Softness & $7.167 \pm 0.279$ & $6.625 \pm 0.221$ & $7.000 \pm 0.023$ & $2.837^{\text {ns }}$ & 0.242 \\
\hline Stickiness & $6.750 \pm 0.250$ & $6.458 \pm 0.344$ & $7.042 \pm 0.024$ & $1.526^{\text {ns }}$ & 0.466 \\
\hline $\begin{array}{c}\text { Mouth } \\
\text { Coating }\end{array}$ & $7.083 \pm 0.083$ & $6.917 \pm 0.083$ & $6.667 \pm 0.124$ & $6.998^{\text {ns }}$ & 0.030 \\
\hline $\begin{array}{c}\text { Overall } \\
\text { acceptabilty }\end{array}$ & $7.125 \pm 0.155$ & $6.708 \pm 0.187$ & $6.792 \pm 0.198$ & $2.855^{\text {ns }}$ & 0.240 \\
\hline
\end{tabular}

ns- Non significant. The values are expressed as their Mean \pm Standard error. (Number of observations =24) \# - based on eight point hedonic scales. 1- extremely low and 8- extremely high

$\mathrm{T}_{1}-0.3$ per cent Aloe vera (AV)

$\mathrm{T}_{2}-0.6$ per cent Aloe vera (AV)

$\mathrm{T}_{3}-0.9$ per cent Aloe vera (AV)

Water Absorption Index relatively increased with addition of the AV may be due to gelation property of the AV. Park and Baik (2002) quoted that Water Absorption Capacity of food sample is the power to hold water within its internal structure affected by factors such as quality protein content, starch damage and physical properties of flour etc. The swelling Power Index relatively increased with the increase in AV in the noodles because of better absorption capacity. Saibuatong et al., (2010) found increased water absorption of edible films because of the hydrophilic components present in the AV.

\section{Colour ( $\mathbf{L} * \mathbf{a} * \mathbf{b} *$ values $)$}

The Colour parameters of the functional chicken noodles with addition of different levels of Aloe vera (AV) in $T_{1}, T_{2}, T_{3}$ at 0.3 per cent, 0.6 per cent and 0.9 per cent respectively are presented in Table 2.

The lightness, redness and yellowness did not show any significant difference between the test samples and the values were in the range of $43.755-44.212,13.298-13.555$ and 30.475 - 30.637. The redness and yellowness values of chicken noodles reduced with addition of Aloe vera (AV) whereas lightness increased relatively. Similarly, Chauhan et al., (2011) found no significant difference for colour parameters upon addition of AV in apple slices and Benitez et al., (2013) also reported same upon addition of AV on Kiwifruit as edible coating.

\section{Sensory evaluation}

The sensory evaluation of chicken noodles with aloevera at 3 different levels are presented in table 3 .

The sensory evaluation revealed no significant difference in appearance and colour, flavour, taste, softness and stickiness. Though there was no significant difference in sensory scores of the test samples the scores were relatively higher for $T_{1}$. The panellists opined that increase in the AV induced slight brightness in 
the chicken noodles and $\mathrm{T}_{1}$ with 0.3 per cent aloe vera had highest score value for overall acceptability. Similarly Devatkal et al., (2010) found no remarkable difference by panellists in sensory scores for flavour and overall acceptability of various types of meat patties incorporated with natural antioxidants. Valverdee et al., (2005) found off flavour and reduction in sweetness of grapes coated with aloe vera gel.

Aloe vera powder above 0.6 per cent incorporation in chicken noodles imparted bitterness and it was not accepted by panellists. The noodles with 0.3 aloe vera powder incorporated chicken noodles had better sensory scores. Aloe vera can improve the water hydration properties of the chicken noodles. Thus, functional chicken noodles with better acceptability and nutritive value could be prepared by incorporating Aloe vera powder upto0.3 per cent in the formulation without affecting the sensory attributes.

\section{References}

AOAC. 2012. Official methods of analysis of official analytical chemists. $\left(19^{\text {th }} \mathrm{Ed}\right.$.) AOAC Int., Gaithersburg, USA.

Berry, B.W. and Wergin, W.P. 1992. Modified pregelatinized potato starch in low-fat ground beef patties. $J$. Muscle Foods. 4: 305-320.

Carbonell, L.A., Lopez. J.F., Perez-Alvarez, J.A and Kuri, V. 2005. Characteristics of beef burger as influenced by various types of lemon albedo. Innov. Food Sci. and Emerg. Technol.6:247-255.

Chauhan, O.P., Raju, P.S., Singh, A., Bawa, A.S., 2011. Shellac and aloe-gel-based surface coatings for maintaining keeping quality of apple slices. Food Chem. 126,961-966.

Devatkal, S.K., Narsaiah, K. and Borah, A. 2010. Anti-oxidant effect of extracts of kinnow rind, pomegranate rind and seed powders in cooked goat meat patties. Meat Sci. 85(1), pp.155-159.

Jiang, J. and Xiong, Y.L., 2016. Natural antioxidants as food and feed additives to promote health benefits and quality of meat products: A review. Meat science, 120, pp.107-117.

McCarthy, T.L., Kerry, J.P., Kerry, J.F., Lynch, P.B. and Buckley, D.J., 2001. Evaluation of the antioxidant potential of natural food/plant extracts as compared with synthetic antioxidants and vitamin $\mathrm{E}$ in raw and cooked pork patties. Meat Sci. 58(1), pp.45-52.

Naveena, B. M., Sen, A. R., Vaithiyanathan, S., Babji, Y., and Kondaiah, N. (2008). Comparative efficacy of pomegranate juice, pomegranate rind powder extract and BHT as antioxidants in cooked chicken patties. Meat Sci. 80,304-308.

Ohishi, K., Kasai, M., Shimada, A. and Hatae, K. 2007. Effects of acetic acid on the rice gelatinization and pasting properties of rice starch during cooking. Food Res. Int.40(2), pp.224231.

Page, J.K., Wulf, D.M. and Schwotzer, T.R. 2001. A survey of beef muscle colour and pH. J. Anim. Sci.79: 678-687.

Park, C.S. and Baik, B.K. 2004. Relationship between protein characteristics and instant noodle making quality of wheat flour. Cereal Chem. 81(2). pp.159-164.

Qin, Y.Y., Zhang, Z.H., Li, L., Xiong, W., Shi, J.Y., Zhao, T.R. and Fan, J. 2013. Antioxidant effect of pomegranate rind powder extract, pomegranate juice, and pomegranate seed powder extract as antioxidants in raw ground pork meat. Food Sci. and Biotech. 22(4). pp.1063-1069.

S. Benitez, I. Achaerandio, F. Sepulcre, M. Pujola 2013. Aloe vera based edible coatings improve the quality of minimally processed 'Hayward' kiwifruit. Postharvest Biology and 
Technol.81 (2013) 29-36.

Saibuatong, O.A. and Phisalaphong, M. 2010. Novo aloe vera-bacterial cellulose composite film from biosynthesis. Carbohydrate Polymers, 79(2). pp.455-460.

Saritha V, Anilakumar KR, Farhath K. Antioxidant and antibacterial activity of Aloe vera gel extracts 2010. Int. J Pharma. Bio. Archives. 1(4):376-384.

Sirichokworrakit, S., Phetkhut, J. and Khommoon, A., 2015. Effect of partial substitution of wheat flour with rice berry flour on quality of noodles. Procedia-Social and Behavioral Sci. 197, pp.1006-1012.

Valverde, J. M., Valero, D., MartínezRomero, D., Guillén, F., Castillo, S. and Serrano, M. (2005). Novel edible coating based on aloe vera gel to maintain table grape quality and safety. J. of Agric. and Food Chem.53(20). 7807-7813.

Vogler, B and Ernst, E. (1999). Aloe vera: A systematic review of its clinical effectiveness. The British J. of General Practice. 49(447). 823-828.

\section{How to cite this article:}

Pavan, M., T. Sathu, B. Sunil, V. N. Vasudevan, A. Irshad and Silpa Sasi. 2019. Effect of Different Level of Natural Antioxidant Aloe vera in Instant Functional Chicken Noodles. Int.J.Curr.Microbiol.App.Sci. 8(10): 1850-1857. doi: https://doi.org/10.20546/ijcmas.2019.810.215 